DOI 10.15393/j9.art.2019.5961

УДК 821.161.1.09“18”

Игорь Васильевич Кудряшов

(Арзамас, Российская Федерачия)

kiv.arz@yandex.ru

\title{
Об источниках образного определения А. С. Пушкина как «соднца Поэзии»
}

Аннотация. Статья посвящена проблеме источников краткого извещения о смерти А. С. Пушкина, напечатанного 30 января 1837 г. в 5-м номере «Литературных прибавлений» - приложении к газете «Русский инвалид». Ранее исследователями установлено, что его автором является В. Ф. Одоевский. Доказывается, что семантика образного определения значения Пушкина как «солнца русской поэзии» восходит у В. Ф. Одоевского к Библии, в которой символика солнца имеет тождественные извещению коннотации. Значимым источником образа «солнца поэзии» в некрологе Одоевского бесспорно выступает и творческое наследие самого Пушкина, в котором дневное светило предстает величественным, сакральным источником жизни, преисполненным истинной Божественной мудрости, несущим людям радость и счастье и указующим спасительный путь. Данная семантика образа прослеживается в стихотворениях «Вакхическая песня», «Из Barry Cornwall» («Пью за здравие Мери...»), в критической статье «Торжество дружбы, или Оправданный Александр Анфимович Орлов» и последней прижизненной публикации великого поэта в «Литературных прибавлениях» - стихотворении «Аквилон». Текстуальное сближение определения значения Пушкина, данного в некрологе Одоевским, со словами митрополита Киевского Кирилла «солнце отечества закатилось» из «Истории государства Российского» Н. М. Карамзина, восходящими к «Степенной книге», объясняется общим библейским первоисточником.

Ключевые слова: А. С. Пушкин, В. Ф. Одоевский, некролог, диалог, реминисценции, библейская традиция, семантика, образ, метафора

Об авторе: Кудряшов Игорь Васильевич - доктор филологических наук, профессор кафедры русского языка и литературы, Арзамасский филиал Нижегородского государственного университета им. Н. И. Лобачевского (607220, Российская Федерация, Нижегородская обл., г. Арзамас, ул. К. Маркса, 36)

Дата поступления: 14.03.2019

Дата публикации: 28.06.2019

Для цитирования: Кудряшов И. В. Об источниках образного определения А. С. Пушкина как «солнца поэзии» // Проблемы исторической поэтики. - 2019. - Т. 17. — № 2. - C. 67-85. DOI: 10.15393/j9.art.2019.5961 
Солнцу поэзии русской хвала, Слава носителю света, Жрицею правды священной была Светлая муза поэта.

Чюмина О. «Гимн Пушкину» ${ }^{1}$

Образное определение А. С. Пушкина в национальной литературе - «солнце русской поэзии», - как известно, восходит к краткому извещению о его смерти, напечатанному 30 января 1837 г. в 5-м номере «Литературных прибавлений»², которые издавались под редакцией А. А. Краевского в качестве приложения к газете «Русский инвалид» и выходили в Петербурге еженедельно по субботам. Авторство извещения о смерти Пушкина достаточно долгое время приписывалось редактору издания, однако Р. Б. Заборовой в статье «Неизданные статьи В. Ф. Одоевского о Пушкине» (1956) было установлено, что текст некролога был написан В. Ф. Одоевским (1804-1869) [3аборова: 320-328], который в декабре 1836 г. стал соредактором «Литературных прибавлений» [Гусев: 18]. Заборова убедительно доказала верность предположения, сделанного еще в начале XX в. П. Н. Сакулиным (см.: [Седова: 205]). Еще одним подтверждением принадлежности некролога перу В. Ф. Одоевского стала публикация И. Андрониковым письма дочери известного историка Софьи Николаевны Карамзиной к брату Андрею Николаевичу от 10 февраля 1837 г. в журнале «Новый мир» (см.: [Андроников: 195]).

Некролог великому поэту был размещен на последней странице номера и следовал непосредственно за рубрикой «Литературное известие», предшествуя лишь заключительным разделам газеты - «Смесь» и «Моды». Извещение о смерти Пушкина (что обращает на себя внимание!) не было отнесено редактором издания к имеющимся в номере разделам. Приведем эти несколько трогательных строк, вырвавшихся из самой глубины души Одоевского в трагический час кончины Пушкина, в том виде, в котором они были помещены на последней странице «Литературных прибавлений»: 
Солнце нашей Поэзіи закатилось ! Пушкинъ скончался, скончался во цвђТъ АБтъ, въ срединъ своего великаго поприща !... Болье говорить о семъ не имъемъ силы, да и не нужно; всякое Русское сердце знаеть всю џьну этой невозвратимой потери, и всякое Русское сердџе будетъ растерзано. Пушкинъ! нашъ поэтъ! наша радость, наша народная слава!... Не ужьли въ самомъ Аъ.ъ нътъ уже у насъ Пушкина ?... Къ этой мысли нельзя привыкнуть!

29 января, 2 ч. 45 м. по полудни.

Внераздельное расположение некролога Пушкину, как, впрочем, и отсутствие отдельного некрологического раздела, куда могло бы быть помещено редактором извещение о смерти поэта, объясняется тем, что ко времени кончины Пушкина 29 января - номер уже прошел цензуру П. Корсакова. Скорбная информация, занявшая 10 строк полосы, по всей видимости, была спешно втиснута в уже одобренный Цензурным ведомством и находящийся в типографском наборе номер, изначально, конечно же, не предполагавший некрологического раздела. Изменить рубрикацию номера, получившего цензурное дозволение к печати, редактор Краевский не имел законного права, а известить читателя о кончине первого национального поэта, печатавшегося на страницах издания, было крайне необходимо. Краевский нашел выход: он не только проинформировал своего читателя, но и отдал посмертную дань величию пушкинского гения, достойную царствующих особ, членов их семей, выдающихся полководцев и государственных деятелей. Несколько строк, извещавших о смерти Пушкина, были помещены им на последней странице номера между разделами и на этом формальном основании были отделены рамкой от рубрик «Литературное известие», «Смесь» и «Моды». Фактически же скорбные строки о кончине поэта обрамлены черной траурной каймой, которая впоследствии, уже после выхода номера в свет, вызвала крайнее недовольство министра народного просвещения С. С. Уварова, известное из библиографического очерка П. А. Ефремова [Ефремов: 537]. Заметим, что в соответствии с этикетом российской периодики того 
времени извещение о смерти Пушкина - «человека не чиновного», не занимавшего высокого положения на государственной службе и не сродственного членам императорской семьи могло быть помещено в периодическом печатном издании, но без траурной рамки, как то было сделано редактором «Северной пчелы», опубликовавшим в тот же день, 30 января 1837 г., в 24-м номере газеты написанный Л. А. Якубовичем некролог поэту в разделе «Внутренние известия» ${ }^{3}$.

Уже на следующий день после публикации некролога Пушкину в «Литературных прибавлениях» А. А. Краевский был вызван к попечителю Санкт-Петербургского учебного округа князю М. А. Дундукову-Корсакову, совмещающему обязанности председателя цензурного комитета, который передал ему слова крайнего недовольства министра С. С. Уварова: «К чему эта публикация о Пушкине? Что это за черная рамка вокруг известия о кончине человека не чиновного, не занимавшего никакого положения на государственной службе? Ну, да это еще куда бы ни шло! Но что за выражения! "Солнце поэзии!!”, помилуйте, за что такая честь? “Пушкин скончался... в средине своего великого поприща!" Какое это такое поприще? Сергей Семенович именно заметил: разве Пушкин был полководец, военачальник, министр, государственный муж?! Наконец, он умер без малого сорока лет! Писать стишки не значит еще, как выразился Сергей Семенович, проходить великое nоприще! Министр поручил мне сделать вам, Андрей Александрович, строгое замечание...» [Ефремов: 537]. Слова министра, переданные Краевскому председателем цензурного комитета Дундуковым-Корсаковым, требуют пояснения. Из монолога следует, что крайнее раздражение министра вызвала не столько черная рамка, обрамляющая извещение о смерти поэта Пушкина, сколько содержательная часть некролога, в котором поэт именуется «солнцем поэзии», а его литературная деятельность - «великим поприщем». Траурную рамку извещению о смерти человека низкого социального статуса, к которому относились в то время литераторы, власти готовы были простить редактору (вспомним фразу «Ну, да это еще куда бы ни шло!»), но лишь потому, что еще с 20-х гг. XIX в. публикация некрологов в российской периодике стала достаточно обыденным явлением, в том числе и лицам, обладающим 
не самым высоким статусом: литераторам, купцам, музыкантам, ученым, врачам (см. [Кузовкина: 276-293], [Рейтблат: 195-202]). И траурная кайма, обрамляющая извещение о смерти поэта, с учетом отсутствия в данном номере газеты соответствующей рубрики, конечно же, выделялась на общем фоне, нарушала общепринятые правила, но уже не воспринималась вопиющим попранием этикетных норм, принятых в российской периодической печати того времени.

Еще большее раздражение у Уварова вызвало проведенное автором некролога сравнение жизненного пути поэта с прохождением «великого поприща». Это, по мнению министра, категорически не может быть применимо к человеку, «писавшему стишки» и окончившему земной путь «без малого сорока лет». О враждебном неприятии поэта Уваровым, который не смог простить «На выздоровление Лукулла» и «остался смертельным врагом Пушкина и после его роковой смерти», многократно писалось в биографической литературе (см.: [Ефремов: 532-538], [Виттекер], [Иванов: 45-55], [А. С. Пушкин в воспоминаниях современников] и др.). Отношение министра к поэту во многом объясняет его реакцию на содержание некролога. Однако и по сей день остаются без ответа вопросы Уварова, адресованные через попечителя Санкт-Петербургского учебного округа редактору издания Краевскому, которому, как известно, «ничего не оставалось, чтобы успокоить "попечителя”, как сослаться на то, что Пушкину было, по высочайшей воле, поручено составление истории царствования Петра Великого и вот едва были собраны им материалы, едва готов он был писать историю, - с поприща (курсив мой. И. К.) этого труда смерть похитила историографа и поэта» [Ефремов: 537]. Оправдание, которое нашел Краевский, по меньшей мере, странное, граничащее с нелепостью: в «великую» заслугу Пушкину ставится не то, что он сделал при жизни (на жизненном поприще), а то, что только собирался, но не успел из-за смерти исполнить «высочайшую волю». Понять такое оправдание редактора Краевского можно: он не был автором «этих нескольких теплых, глубоко прочувствованных строк» [Ефремов: 536], извещающих читателя его издания о кончине Пушкина, и в то же время, наверняка, был 
хорошо осведомлен о министерском благорасположении к идее исторического просвещения российской молодежи.

В научной литературе утвердилась точка зрения, согласно которой вероятным источником образного сравнения Пушкина с «солнцем нашей Поэзии» стал для Одоевского текст «Истории государства Российского» Н. М. Карамзина, восходящий к первоисточнику - памятнику русской литературы второй половины XVI в. «Степенной книге». Весьма показательна в этом отношении статья, представленная в «Энциклопедическом словаре крылатых слов и выражений» (2005) автора-составителя В. В. Серова:

«Возможно (курсив мой. - И. К.), что выражение “солнце нашей поэзии закатилось” было навеяно В. Ф. Одоевскому другим, весьма схожим, из “Истории государства Российского” (т. 4, гл. 2) Н. М. Карамзина. Там историк повествует, как на Руси восприняли весть о смерти Александра Невского в 1263 г. Митрополит Киевский Кирилл, “сведав о кончине великого князя.., в собрании духовенства воскликнул: “Солнце отечества закатилось”. Никто не понял сей речи. Митрополит долго безмолвствовал, залился слезами и сказал: “Не стало Александра!” Все оцепенели от ужаса, ибо Невский казался необходимым для государства и по летам своим мог бы жить еще долгое время".

Для самого же Карамзина первоисточником послужил памятник русской литературы второй пол. XVI в. “Степенная книга”, в котором впервые на Руси была сделана попытка собрать воедино исторические сведения, содержащиеся в разных русских летописях. Фраза из “Степенной книги” звучит так: “Уже заиде солнце земьля Руськія"»".

Обращает на себя внимание, что автор словарной статьи лишь допускает возможность того, что слова митрополита Киевского Кирилла из «Истории государства Российского» могли послужить источником, навеявшим Одоевскому сравнение Пушкина с «солнцем нашей Поэзии». Это уже само по себе свидетельствует о недостаточной убежденности авторасоставителя издания, а следовательно, о гипотетичности и небесспорности представленной в энциклопедическом словаре концепции. По всей видимости, текстовое сближение некролога Пушкину с «Историей государства Российского» 
было обусловлено не сознательной авторской отсылкой к памяти читателя, а возникшей невольной реминисценцией историко-культурного плана, апеллирующей к горестному событию российской истории: кончине великого князя Киевского и Владимирского, полководца Александра Невского, которого с поэтом сближают общее имя Александр и ранняя смерть. Данная реминисценция укреплялась в читательском сознании на протяжении достаточно долгого времени, по мере общественного осмысления значимости вклада Пушкина в отечественную и мировую культуру, что позволило соотнести личности великого полководца и великого поэта. В этом отношении показательно издание М. Г. и Н. С. Ашукиных «Крылатые слова. Литературные цитаты. Образные выражения» (1955), в котором авторы лишь отмечают «сходное по мысли выражение», приведенное Н. М. Карамзиным в «Истории государства Российского», не указывая на него как на возможный источник образного выражения «солнце русской поэзии» ${ }^{5}$.

Что же тогда могло навеять Одоевскому начальную фразу некролога «Солнце нашей Поэзии закатилось!», сходство которой со словами киевского митрополита Кирилла из «Истории государства Российского» было подмечено литературоведами спустя значительное время? Подобного рода текстовые сближения могли возникнуть, по всей видимости, благодаря наличию такого общего оригинального первоисточника, как библейский текст. В этом случае и высказывание киевского митрополита, зафиксированное древнерусским автором в «Степенной книге», а оттуда заимствованное Карамзиным в текст «Истории государства Российского», и образное сравнение из написанного Одоевским некролога выступают в качестве библейских реминисценций. Обращение к библейскому тексту, его образности, мотивам и постулатам при извещении о смерти (в нашем случае митрополита Кирилла - «в собрании духовенства» и Одоевского - в извещении православных читателей «Литературных прибавлений») мотивировано целью сообщить горестное известие о кончине и характерно как для обращения духовного пастыря (митрополита) к пастве (священнослужителям), так и для первых некрологов Российской Империи, в которых смерть соотносилась с христианским 
религиозно-богословским пониманием окончания земного пути (иначе, поприща) человека и бессмертия бытия его души (см.: [Онипко: 83-87]).

Попутно заметим, что данный христианский религиознобогословский контекст извещения о кончине Пушкина как в тексте Одоевского в «Литературных прибавлениях», так и в тексте Якубовича в «Северной пчеле» изначально мотивировал употребление обоими авторами слова «поприще» по отношению к окончившемуся земному пути национального поэта. В то же время, в отличие от Якубовича, у которого употребление данного слова дополнительно мотивировано литературными заслугами покойного национального масштаба, по отношению к которым «Россия обязана Пушкину благодарностью...» ${ }^{6}$, у Одоевского употребление сочетания «великое поприще», в середине которого закончил свой земной путь Пушкин, обусловлено контекстом: славой первого национального поэта, «радости» России, чувством народной гордости и любви. Однако это лишь отчасти объясняет эпитет «великий», употребленный Одоевским по отношению к земному пути («поприщу») поэта. Некролог Пушкину Одоевского выражает православное миросозерцание его автора, и в то же время в нем специфически осмысливаются христианские качества покойного, чья «светлая муза» была «жрицею правды священной»7. Еще Н. В. Измайлов справедливо заметил, что «Одоевский видел в Пушкине чистейшее воплощение идеала поэта как продукта высшей деятельности человеческого духа, как провидца, обладающего непосредственным знанием и в полной мере способностью передавать свои постижения» [Измайлов: 309]. Художественное творчество, как и его восприятие, сопряжено, по мнению Одоевского, с особым родом «религиозного акта, совершаемого душою в своем неприступном святилище» [Измайлов: 309]. Употребляя в некрологе эпитет «великий» по отношению к жизненному пути («поприщу») Пушкина, Одоевский утверждает непосредственную сопричастность творчества скончавшегося поэта, открывавшего читателю «завесу с таинств души», Высшему миру, Божественному Началу. В этом отношении Поэт сродни Богу и потому, считал Одоевский, «пред великим художником 
важно и полезно лишь одно чувство: благоговение» (цит. по: [Заборова: 335]). Православное миросозерцание Одоевского и специфика его осмысления предназначения поэта полнее проясняют и мотивируют использование им в горестном и патетическом некрологе Пушкину эпитета «великий» и согласуются с творческой концепцией самого Пушкина, который, как справедливо отметила Э. С. Лебедева, «свой гений понимал как дар Божий» [Лебедева: 145].

Истоки образно-оценочной характеристики Одоевским гибели Пушкина - «Солнце нашей Поэзии закатилось!» коренятся, на наш взгляд, в библейском тексте, который, очевидно, послужил первоисточником и для высказывания киевского митрополита Кирилла, зафиксированного древнерусским автором в «Степенной книге» и оттуда заимствованного Карамзиным для «Истории государства Российского». В Библии содержится 150 упоминаний о солнце, в том числе и многочисленные о «закатившемся» солнце. В отличие от «помрачения» солнца и других небесных светил, встречающихся в Библии в апокалиптических видениях о грядущих космических коллизиях и символизирующих Божий суд, «закатившееся» солнце символизирует великую скорбь народов мира и в ряде случаев непосредственно соотносится с окончанием земного бытия человека, угасанием Жизни. Например: «Лежит в изнеможении родившая семерых, ucnyскает дыхание свое; еще днем закатилось солние ее (курсив мой. - И. К.), она постыжена и посрамлена. И остаток их предам мечу пред глазами врагов их, говорит Господь» (Иер. 15:9); «И когда ты угаснешь, закрою небеса и звезды их помрачу, солние закрою облаком (курсив мой. - И. К.), и луна не будет светить светом своим» (Иез. 32:7); «И будет в тот день, говорит Господь Бог: произведу закат солни, в полдень и омрачу землю среди светлого дня (курсив мой. - И. К.)» (Ам. 8:9) и др. Помимо семантики умирания (смерти), сопряженной с образом закатившегося солнца, в Библии имеются метафорические значения небесного светила, которые создают дополнительный смысловой контекст образу «солнце поэзии» в некрологе Одоевского. Например, библейское описание преображения Господня, в котором лицо Иисуса просияло, как солнце: «По 
прошествии дней шести, взял Иисус Петра, Иакова и Иоанна, брата его, и возвел их на гору высокую одних, и преобразился пред ними: и просияло лице Его, как солнце, одежды же Его сделались белыми, как свет» (Мф. 17:1-2), - навевает читателю ассоциацию с вознесением души Пушкина на небеса. Или сравнение окончивших земной путь праведников с воссиявшим солнцем в тексте Библии: «...тогда праведники воссияют, как солнце, в Царстве Отца их. Кто имеет уши слышать, да слышит!» (Мф. 13:43), - рождает аналогию с праведностью личностных качеств погибшего на дуэли поэта. Еще более прочные ассоциации возникают при обращении к тексту «Откровения Иоанна Богослова». Сравнение с солнцем лица Ангела, держащего в руке раскрытую книгу пророчеств о дальнейших судьбах мира и человечества, вызывают в сознании читателя коннотацию с провидческим характером творческого наследия великого поэта: «И видел я другого Ангела сильного, сходящего с неба, облеченного облаком; над головою его была радуга, и лице его как солнце, и ноги его как столпы огненные, в руке у него была книжка раскрытая» (Откр. 10:1).

Потрясенный известием о гибели поэта, Одоевский пишет «трогательные своей чуткостью и скорбью о Пушкине» (С. Н. Карамзина) [А. С. Пушкин в воспоминаниях современников: 384] несколько строк некролога под влиянием библейского текста, к которому, ища утешения своему сердцу, невольно обратились его мысли. Именно библейские реминисценции делают текст некролога Пушкину столь значительным и проникновенным, близким и понятным каждому читателю «Литературных прибавлений».

В аспекте концептосферы библейского первоисточника сравнение Одоевским погибшего на дуэли поэта с закатившимся солнцем «в середине своего великого поприща» служит отсылкой памяти читателя к Псалму 18, в котором солнце в своем передвижении по небу «радуется, как исполин, пробежать поприще» (Пс. 18:6). Ликование псалмопевца сменяет противоположное чувство автора некролога: скорбь о преждевременно утраченном источнике «нашей радости» - жизни поэта Пушкина. 
Одоевский не был первым, кто использовал библейскую реминисценцию погасшего светила. Ко времени создания некролога Пушкину в отечественной литературе уже сложилась традиция художественного использования этого библейского образа-символа, начало которой, как известно, было положено еще древнерусским автором «Слова о полку Игореве»:

«Два солнца померкли,

Два багряных столпа угасли,

А с ними и два молодые месяца, Олег и Святослав, Тьмою подернулись»;

«Но уже для Игоря-князя солнце свет свой утратило...»9.

Показательно в этом отношении и сочинение К. Н. Батюшкова «Выздоровление» (1807-1809), которое Пушкин считал «одной из лучших элегий» поэта:

«Как ландыш под серпом убийственным жнеца

Склоняет голову и вянет,

Так я в болезни ждал безвременно конца,

И думал: Парки час настанет.

Уж очи покрывал Эреба мрак густой, ${ }^{10}$

Уж сердце медленнее билось:

Я вянул, исчезал, и жизни молодой,

Казалось, солнце закатилось» ${ }^{11}$.

В «Выздоровлении» художественная соотнесенность болезненного увядания лирического героя с кажущимся ему преждевременным закатом солнца восходит к библейскому образу «закатившегося солнца» и символизирует у Батюшкова приближающийся безвременный конец земного бытия героя, скорбящего об ушедшей радости прежней, полной здоровья жизни.

Для осмысления образа «закатившегося солнца» значимо функционирование образа дневного светила в поэтическом творчестве самого погибшего поэта. Для Пушкина солнце это, прежде всего, величественный, сакральный источник жизни, преисполненный истинной Божественной мудрости, несущий людям радость и счастье и указующий спасительный путь. В таком символическом значении выступает солнце, например, в пушкинском стихотворении «Вакхическая песня», 
которое М. О. Гершензон справедливо назвал «гимном вдохновенному разуму, уму-солнцу, которому ясно противопоставляется “ложная мудрость” холодного, расчетливого ума» [Гершензон: 231]:

«одымем стаканы, содвинем их разом!
Да здравствуют музы, да здравствует разум!
Ты, солнце святое, гори!
Как эта лампада бледнеет
Пред ясным восходом зари,
Так ложная мудрость мерцает и тлеет
Пред солнцем бессмертным ума.
Да здравствует солнце, да скроется тьма!»"2

Показательно и пушкинское стихотворение «Из Barry Cornwall» («Пью за здравие Мери»), в котором поэт обращается к героине с благодарностью за то солнце, какое она зажгла в его жизни, со словами привета и пожелания счастья:
«Будь же счастлива, Мери,
Солнце жизни моей!
Ни тоски, ни потери,
Ни ненастливых дней
Пусть не ведает Мери» ${ }^{13}$.

Известно также и пушкинское образное выражение «два блистательных солнца нашей словесности» из напечатанной в «Телескопе» статьи «Торжество дружбы, или Оправданный Александр Анфимович Орлов» (1831), в которой Пушкин использует этот яркий образ в ироническом значении, именуя так двух русских литераторов своего времени: Ф. В. Булгарина и А. А. Орлова ${ }^{14}$. Это свидетельствует о том, что слово «солнце» в переносном значении «человека знаменитого, известного своей выдающейся деятельностью на каком-нибудь поприще» ${ }^{15}$ в начале XIX в. становится широкоупотребительным.

Напечатанный от имени редакции «Литературных прибавлений к "Русскому инвалиду"» некролог Пушкину «Солнце нашей Поэзии закатилось...» - это своего рода итог, завершающий неожиданно оборвавшийся диалог великого поэта с читателями издания. Известно, что для первого номера «Литературных прибавлений», вышедшего из печати 
2 января 1837 г., Одоевский и Краевский в конце декабря 1836 г. получили от Пушкина стихотворение «Аквилон» («Зачем ты, грозный аквилон...») (1824), положившее начало диалогу поэта и читателя нового издания Краевского. Стихотворение было написано Пушкиным в первые месяцы Михайловской ссылки, подверглось им переработке в Болдино (см.: [Бодрова: 85-102]), но опубликовано было лишь в 1837 г., всего за несколько недель до смерти поэта. Р. В. Иезуитова, проанализировав работу Пушкина над текстом этого стихотворения, пришла к убедительному выводу о том, что Пушкин рассматривал его как в определенной степени программное произведение [Иезуитова: 143], а следовательно, публикация «Аквилона» в дебютном номере «Литературных прибавлений» предполагала дальнейшее развитие диалога Пушкина с подписчиками издания. Стихотворение заканчивается жизнеутверждающим образом «ясноликого солнца», вселяющего радость и дарящего надежду на светлое будущее:
«Пускай же солнца ясный лик
Отныне радостью блистает,
И облачком зефир играет,
И тихо зыблется тростник» ${ }^{16}$

Уже в 5-м номере газеты «Литературные прибавления» от 30 января 1837 г. помещается некролог Пушкину, который не только информирует о смерти поэта, но и подводит черту под его неожиданно оборвавшимся диалогом с читателями. В этой связи источником, навеявшим Одоевскому образное сравнение смерти великого поэта с закатившимся солнцем, могли стать жизнерадостные финальные строки «Аквилона», содержащие образ «блистающего радостью» «ясноликого солнца». В творческом сознании Одоевского, которого с Пушкиным связывали не только деловые, но и дружеские, доверительные отношения (см.: [Измайлов: 303-304], [Турьян: 183], [Cornwell: 241-247]), вселяющие радость жизни строки этого стихотворения трансформировались в извещении о смерти в трогательный и преисполненный искренней скорби образ «закатившегося солнца» русской поэзии. Не выходя за рамки темы статьи, заметим, что по мере общественного осмысления значения вклада Пушкина в отечественную культуру образное 
определение «солнце нашей Поэзии» из некролога Одоевского приобрело иную смысловую интерпретацию и стало устойчивым выражением, определяющим пушкинскую индивидуальность. Одно из лучших определений ей дал В. С. Непомнящий в статье «Феномен Пушкина и исторический жребий России: К проблеме целостной концепции русской культуры»: “Солнечность” - свет, тепло, жизнетворность, центральность - вот единственное общепризнанное у нас определение “специфики" явления, носящего имя Пушкин. Его центральная в культуре роль вне сомнения» [Непомнящий: 10].

Таким образом, для В. Ф. Одоевского источниками образного определения Пушкина как «солнца русской поэзии» послужили как библейские солярные образы, так и пушкинские произведения, в которых образ солнца реализует тождественную извещению Одоевского о смерти поэта семантику: стихотворения «Вакхическая песня», «Из Barry Cornwall» («Пью за здравие Мери»), критическая статья «Торжество дружбы, или Оправданный Александр Анфимович Орлов» и стихотворение «Аквилон», ставшее последней прижизненной публикацией великого поэта в «Литературных прибавлениях».

\section{Примечания}

1 Чюмина О. Гимн Пушкину // Новый Мир. 1899. № Х. С. 190.

2 См.: Одоевский В. Ф. Извещение о смерти А. С. Пушкина // Литературные прибавления к «Русскому инвалиду». 1837. № 5 (30 янв.). С. 48.

3 См.: Якубович Л. <Некролог Пушкину> // Северная пчела. 1837. № 24 (30 января). С. 94.

4 Энциклопедический словарь крылатых слов и выражений: Более 4000 статей / авт.-сост. В. Серов. 2-е изд. М.: Локид-Пресс, 2005. С. 717.

5 См.: Ашукин Н. С., Ашукина М. Г. Крылатые слова. Литературные цитаты. Образные выражения. М.: Гослитиздат, 1955. С. 514-515.

6 Якубович Л. <Некролог Пушкину>. С. 94.

7 Чюмина О. Гимн Пушкину. С. 190.

8 Жуковский В. А. Слово о полку Игореве // Жуковский В. А. Полн. собр. соч. и писем: в 20 т. М.: Языки славянских культур, 2010. Т. 5: Эпические стихотворения. С. 16.

9 Там же. С. 18.

10 Первоначальный вариант строфы: «Уж очи покрывал смертельный мрак густой».

11 Батюшков К. Н. Выздоровление («Как ландыш под серпом убийственным жнеца...») // Батюшков К. Н. Сочинения. М.; Л.: Academia, 1934. С. 67. 
12 Пушкин А. С. Вакхическая песня («Что смолкнул веселия глас?..») // Пушкин А. С. Полн. собр. соч.: в 16 т. М.; Л.: Изд-во АН СССР, 1947. Т. 2. Кн. 1: Стихотворения, 1817-1825. Лицейские стихотворения в позднейших редакциях. С. 420.

13 Пушкин А. С. Из Barry Cornwall // Пушкин А. С. Полн. собр. соч., 1837-1937: в 16 т. М.; Л., 1949. Т. 3. Кн. 2: Стихотворения, 1826-1836. Сказки / ред. М. А. Цявловский, Т. Г. Цявловская-Зенгер. С. 259.

14 См.: Пушкин А. С. Торжество дружбы, или Оправданный Александр Анфимович Орлов // Пушкин А. С. Полн. собр. соч.: в 10 т. Л.: Наука, 1978. Т. 7: Критика и публицистика. С. 168-175.

15 См.: Словарь языка Пушкина: в 4 т. / АН СССР, Ин-т языкознания; гл. ред.: акад. В. В. Виноградов (отв. ред.) и др. М.: Государственное изд-во иностранных и национальных словарей, 1961. Т. 4. С. 278.

16 Цит. по: Пушкин А. С. Аквилон («Зачем ты, грозный Аквилон...») // Литературные прибавления к Русскому Инвалиду. 1837. № 1 (2 января). С. 4.

\section{Список литературы}

1. Андроников И. Тагильская находка. Из писем Карамзиных // Новый мир. - 1956. - № 1. - С. 153-209.

2. А. С. Пушкин в воспоминаниях современников: в 2 т. - М.: Худож. лит., 1985. - T. 1. -543 c.

3. Бодрова А. С. Из разысканий вокруг пушкинского «Аквилона» // Пушкинские чтения в Тарту 5: Пушкинская эпоха и русский литературный канон: К 85-летию Ларисы Ильиничны Вольперт: в 2 ч. - Тарту, 2011. - Ч. 1. - С. 85-102.

4. Виттекер Ц. Х. Граф Сергей Семенович Уваров и его время. - СПб.: Гуманитарное агентство «Академический проект», 1999. - 350 с.

5. Гершензон М. Мудрость Пушкина // Пушкин в русской философской критике: Конец XIX - первая половина XX в. - М.: Книга, 1990. C. 207-243.

6. Гусев Н. В. В. Ф. Одоевский - издатель, редактор и журналист (1820-1848 гг.): автореф. дис. ... канд. филол. наук: 10.01.10. — Москва, 2013. $-23 \mathrm{c}$.

7. [Ефремов П. А.] Александр Сергеевич Пушкин. 1799-1837. Биографический очерк и его письма 1831-1837 гг. Гл. XII / сост. под ред. П. А. Ефремова // Русская старина. - 1880. - Т. XXVIII. - Кн. 7. Июль. - С. 532-538.

8. Заборова Р. Б. Неизданные статьи В. Ф. Одоевского о Пушкине // Пушкин: Исследования и материалы. - М.; Л.: Наука, 1956. — Т. 1. — C. $313-342$.

9. Иванов О. А. К вопросу о взаимоотношениях С. С. Уварова и А. С. Пушкина в 30-е гг. ХІХ века // Новик. - Воронеж: ВГУ, 1999. - Вып. 2. C. $45-55$. 
10. Иезуитова Р. В. «Зачем ты, грозный Аквилон...» (О судьбе одного болдинского автографа) // Пушкинский музеум. - СПб.: Дорн, 1999. Вып. 1. - С. 137-143.

11. Измайлов Н. В. Пушкин и В. Ф. Одоевский // Измайлов Н. В. Очерки творчества Пушкина. - Л.: Наука, 1975. - С. 303-325.

12. Кузовкина Т. Некролог Булгарина Жуковскому // Пушкинские чтения в Тарту 3: материалы международной научной конференции, посвященной 220 -летию В. А. Жуковского и 200-летию Ф. И. Тютчева / ред. Л. Киселева. - Тарту: Tartu Ülikooli Kirjastus, 2004. - С. 276-293.

13. Лебедева Э. С. «Таков был конец нашего Пушкина» // Христианство и русская литература. - СПб.: Наука, 1999. - Сб. 3. - С. 139-150.

14. Непомнящий В. С. Феномен Пушкина и исторический жребий России: К проблеме целостной концепции русской культуры // Московский пушкинист: Ежегодный сборник. - М.: Наследие, 1995-.... - Вып. III. 1996. - C. 6-61.

15. Онипко К. А. Первые русские некрологи: герои и контексты // Ученые записки Петрозаводского государственного университета. - 2018. № 1 (170). - C. 83-87 [Электронный ресурс]. — URL: http://uchzap. petrsu.ru/files/redaktor_pdf/1517816954.pdf (20.12.2018). DOI: 10.15393/ uchz.art.2018.14

16. Рейтблат А. И. Писать поперек: статьи по биографике, социологии и истории литературы. - М.: Новое литературное обозрение, 2014. - 415 с.

17. Седова Г. М. Повесть В. Ф. Одоевского «Княжна Зизи» и один из устойчивых мифов о семье Пушкина // Пушкин: Исследования и материалы. - СПб.: Наука, 2004. - T. XVI / XVII. - С. 198-217.

18. Турьян М. А. Из истории взаимоотношений Пушкина и В. Ф. Одоевского // Пушкин: Исследования и материалы. - Л.: Наука, 1983. T. 11. - C. 174-191.

19. Cornwell N. The Life, Times and Milieu of V. F. Odoevsky, 1804-1869. London: The Athlone Press, 1986. - 417 p. 
Igor V. Kudryashov

(Arzamas, Russian Federation)

kiv.arz@yandex.ru

\title{
About the Sources of the Figurative Definition of A. S. Pushkin as "The Sun of Poetry"
}

\begin{abstract}
The article is dedicated to the problem of the sources of a brief notice about the death of A. S. Pushkin, released on January 30, 1837 in the 5th issue of "Literary Additions" ("Literaturnye Pribavleniya") - a supplement to the newspaper "Russian Invalid" ("Russkiy Invalid"). It is proved that the semantics of the figurative definition of the importance of Pushkin as "The sun the Russian poetry" according to V. F. Odoevsky goes back to the Bible, in which the sun's symbolism is equivalent to the connotation of the necrologic notice. A significant source of the image of "the sun of poetry" in Odoevsky's obituary is the creative heritage of Pushkin in which the sun appears as a majestic, sacral source of life, full of true, Divine wisdom, giving people the joy and happiness and pointing at a saving way. This semantics of the image can be seen in the poems "Bacchanal Song", "From Barry Cornwall" ("I Drink to Mary's Health"), in the critical essay "The Triumph of Friendship, or Acquitted Alexander Anfimovich Orlov" and the last lifetime publication of the great poet in "Literary Additions" - the poem "Aquilon". The textual convergence of the definition of the significance of Pushkin given in his obituary by Odoevsky with the words of Metropolitan of Kiev Cyril "the sun of the fatherland set below the horizon" from the "History of the Russian State" by Karamzin, going back to the "Power Book" "Stepennaya Kniga"), is explained by a common biblical authentic source.
\end{abstract}

Keywords: A. S. Pushkin, V. F. Odoevsky, obituary, dialogue, reminiscences, biblical tradition, semantics, image, metaphor

About the author: Kudryashov Igor V. - Doctor of Philology, Professor of the Department of Russian Language and Literature, Arzamas Branch of Lobachevsky State University of Nizhny Novgorod (ul. Karla Marksa 36, Arzamas, Nizhegorodskaya obl., 607220, Russian Federation)

Received: March 14, 2019

Date of publication: June 28, 2019

For citation: Kudryashov I. V. About the Sources of the Figurative Definition of A. S. Pushkin as "The Sun of Poetry" In: Problemy Istoricheskoi Poetiki [The Problems of Historical Poetics], 2019, vol. 17, no. 2, pp. 67-85 (In Russ.)

\section{References}

1. Andronikov I. Tagil Finding. From the Karamzins' Letters. In.: Novyy mir, 1956, no. 1, pp. 153-209. (In Russ.)

2. A. S. Pushkin v vospominaniyakh sovremennikov: $v 2$ tomakh [A. S. Pushkin in Memoirs of His Contemporaries: in 2 Vols]. Moscow, Khudozhestvennaya literatura Publ., 1985, vol. 1. 543 p. (In Russ.) 
3. Bodrova A. S. On the Inquiries into Pushkin's “Aquilon”. In.: Pushkinskiye chteniya $v$ Tartu 5: Pushkinskaya epokha i russkiy literaturnyy kanon: K 85-letiyu Larisy Il'inichny Vol'pert: $v 2$ ch. [Pushkin Readings in Tartu. Vol. 5. The Pushkin Epoch and the Russian Literary Canon: On the Occasion of the 85th Anniversary of the Birth of L. I. Volpert]. Tartu, 2011, part 1, pp. 85-102. (In Russ.)

4. Vitteker Ts. Kh. Graf Sergey Semenovich Uvarov i ego vremya [Count Sergey Uvarov and His Time]. St. Petersburg, Gumanitarnoe agentstvo Akademicheskiy proekt Publ., 1999. 350 p. (In Russ.)

5. Gershenzon M. The Wisdom of Pushkin. In: Pushkin v russkoy filosofskoy kritike: Konets XIX - pervaya polovina XX veka. [Pushkin in the Russian Philosophical Criticism. The End of the 19th and the First Half of the 20th Centuries]. Moscow, Kniga Publ., 1990, pp. 207-243. (In Russ.)

6. Gusev N. V. V. F. Odoyevskiy - izdatel', redaktor i zhurnalist (1820-1848): avtoref. dis. ... kand. filol. [V. F. Odoyevsky Is a Publisher, Editor and Journalist (1820-1848). PhD. philol. sci. diss. abstract]. Moscow, 2013. 23 p. (In Russ.)

7. Efremov P. A. Alexander Sergeevich Pushkin. 1799-1837. Biographical Essay and His Letters. 1831-1837. Chapter 12. In: Russkaya Starina, 1880, vol. 28, book 7 (July), pp. 532-538. (In Russ.)

8. Zaborova R. B. The Unpublished Articles of V. F. Odoyevsky About Pushkin. In: Pushkin: Issledovaniya i materialy [Pushkin: Researches and Materials]. Moscow, Leningrad, Nauka Publ., 1956, vol. 1, pp. 313-342. (In Russ.)

9. Ivanov O. A. On the Question of the Relations Between S. S. Uvarov and A. S. Pushkin in the 1830s. In: Novik. Vypusk 2 [Novik. Issue 2]. Voronezh, Voronezh State University Publ., 1999, pp. 45-55. (In Russ.)

10. Iyezuitova R. V. «Zachem ty, groznyy Akvilon...» (On the History of One Boldin's Autograph). In.: Pushkinskiy muzeum. St. Petersburg, Dorn Publ., 1999, vol. 1, pp. 137-143. (In Russ.)

11. Izmaylov N. V. Pushkin and V. F. Odoevsky. In: Izmaylov N. V. Ocherki tvorchestva Pushkina [Izmaylov N. V. Short Essays on Pushkin's Works]. Leningrad, Nauka Publ., 1975, pp. 303-325. (In Russ.)

12. Kuzovkina T. The Obituary by Bulgarin for Zhukovsky. Pushkinskiye chteniya $v$ Tartu 3: materialy Mezhdunarodnoj nauchnoj konferentsii, posvyashchennoj 220-leyiyu V. A. Zhukovskogo i 200-letiyu F. I. Tyutcheva [Pushkin Readings in Tartu 3: Proceedings of the International Scientific Conference on the Occasion of the 220th Anniversary of the Birth of V. A. Zhukovsky and the 200th Anniversary of the Birth of F. I. Tyutchev]. Tartu, 2004, pp. 276-293. (In Russ.)

13. Lebedeva E. S. "Such Was the End of Our Pushkin". In: Khristianstvo $i$ russkaya literatura. Sbornik 3 ["Such Was the End of Our Pushkin" in Christianity and Russian Literature. Miscellany 3]. St. Petersburg, Nauka Publ., 1999, pp. 139-150. (In Russ.) 
14. Nepomnyashchiy V. S. The Phenomenon of Pushkin and the Historical Lot of Russia: On the Problem of the Integral Concept of Russian Culture. In.: Moskovskiy pushkinist: Ezhegodnyy sbornik [Moskovsky Pushkinist. Annual Digest]. Moskov, Nasledie Publ., 1995-..., issue 3, 1996, pp. 6-61. (In Russ.)

15. Onipko K. A. The First Russian Obituaries: Heroes and Contexts. In: Uchenye zapiski Petrozavodskogo gosudarstvennogo universiteta [Proceedings of Petrozavodsk State University], 2018, no. 1 (170), pp. 83-87. Available at: http://uchzap.petrsu.ru/files/redaktor_pdf/1517816954.pdf (accessed on December 20, 2018). DOI: 10.15393/uchz.art.2018.14 (In Russ.)

16. Reytblat A. I. Pisat' poperek: stat'i po biografike, sotsiologii i istorii literatury [Writing Crosswise: Articles on Biography Studies, Sociology, and Literary History]. Moscow, Novoe literaturnoe obozrenie Publ., 2014. 415 p. (In Russ.)

17. Sedova G. M. V. F. Odoevsky's Story "Princess Zizi” and One of the Persistent Myths About the Family of Pushkin. In: Pushkin: Issledovaniya i materialy [Pushkin: Researches and Materials]. St. Petersburg, Nauka Publ., 2004, vol. 16 / 17, pp. 198-217. (In Russ.)

18. Tur'yan M. A. From the History of the Relationships Between Pushkin and V. F. Odoevsky. In: Pushkin: Issledovaniya i materialy [Pushkin: Researches and Materials]. Leningrad, Nauka Publ., 1983, vol. 11, pp. 174-191. (In Russ.)

19. Cornwell N. The Life, Times and Milieu of V. F. Odoevsky, 1804-1869. London, The Athlone Press Publ., 1986. 417 p. (In English) 